\title{
USPOREDBA IZOBARA GLAVNIH NAPREZANJA DOBIVENIH ANALITIČKI I EKSPERIMENTALNO POLARISKOPOM
}

\author{
COMPARISON OF PRINCIPAL STRESS ISOBARS \\ OBTAINED ANALYTICALLY AND EXPERIMENTALLY \\ USING POLARISCOPE
}

Alen Malagić ${ }^{*}$ Edita Papa Dukić ${ }^{*}$

\begin{abstract}
Sažetak
U radu je provedena analiza izobara glavnih naprezanja na jednostavnom primjeru slobodno oslonjene grede. Analiza je provedena na analitički način koristeći se programskim paketom Wolfram Mathematica te na eksperimentalni način pomoću refleksijskog polariskopa. Pojašnjen je princip rada samog polariskopa te je prikazana priprema uzoraka za ispitivanje ovom vrstom polariskopa. Zatim su dane usporedbe rezultata dobivenih analitički i eksperimentalno, kao i krajnji zaključci i prijedlozi za daljnja istraživanja.
\end{abstract}

Ključne riječi: naprezanje, glavna naprezanja, polariskop, fotoelasticimetrija, izobare glavnih naprezanja

\begin{abstract}
This paper contain analysis of principal stress isobars on a simple beam subjected to a three-point load. Analysis was conducted analytically using software Wolfram Mathematica and experimentally using reflection polariscope. Furthermore, working principle of polariscope is described and the preparation of samples for testing in reflective polariscope are shown. Comparison of results obtained analytically and experimentally are given as well as final conclusions and suggestions for further research.
\end{abstract}

Key words: stress, principal stress, polariscope, photoelasticity, principal stress isobars

\footnotetext{
* Građevinski fakultet Sveučilišta u Rijeci, R. Matejčić 3, Rijeka

E-mail: alen.malagic@student.uniri.hr, edita.papa@gradri.uniri.hr
} 


\section{Uvod}

Pojam naprezanje u građevini ima vrlo raširenu primjenu, kako $\mathrm{u}$ Nosivim konstrukcijama, tako i u svim drugim granama. Zato je potrebno dobro poznavati naprezanja i način njihove realizacije u napregnutim elementima (poprečnim presjecima). Naši proračuni temelje se na kontroli maksimalnih naprezanja, odnosno glavnih naprezanja unutar najnapregnutijeg poprečnog presjeka u elementu. Stoga je cilj ovoga rada odrediti izobare glavnih naprezanja po visini i dužini napregnutog elementa na dva načina:

- analitički - primjenom formula koje proizlaze iz diferencijalnih jednadžbi ravnoteže

- laboratorijskim ispitivanjem pomoću polariskopa

te usporediti dobivene rezultate, čime možemo utvrditi razlike $\mathrm{i}$ netočnosti u rezultatima dobivenim laboratorijskim ispitivanjem $i$ analitičkim proračunom i na osnovi toga utvrditi i pojasniti razloge odstupanja, prednosti i mane određivanja izobara pomoću polariskopa.

Ovim radom želi se studentima i drugim zainteresiranima zorno predočiti pojam izobara glavnih naprezanja na puno jasniji, detaljniji i prihvatljiviji način, nego što je to uočeno prilikom pregledavanja razne literature vezane uz takvu tematiku.

\section{NAPREZANJA}

\subsection{Pojam naprezanja}

Naprezanje u najjednostavnijem obliku predstavlja kvocijent unutarnje sile u promatranom presjeku $\mathrm{F}$ i površine poprečnog presjeka A na koju ta sila djeluje. Stanje naprezanja u nekoj točki definirano je sa 6 komponenti, a prikazujemo ih pomoću tenzora naprezanja. Ovdje su samo navedeni gotovi izrazi koji su korišteni u radu.

\subsection{Glavna naprezanja}

Glavna naprezanja se javljaju u presjecima gdje su pripadajuća tangencijalna naprezanja jednaka nuli, tj. tamo gdje se smjer vektora punog naprezanja podudara sa smjerom vanjske normale. Takve ravnine nazivaju se glavne ravnine, a normalna naprezanja koja djeluju na tim ravninama i ekstremne su vrijednosti normalnih naprezanja nazivaju se glavna naprezanja. Označuju se kao $\sigma_{1}$ i $\sigma_{2}$, gdje je $\sigma_{1}$ maksimalno, a $\sigma_{2}$ minimalno naprezanje [1]. 
Pravci glavnih naprezanja nazivaju se glavnim osima te se još mogu definirati i kao smjerovi glavnih naprezanja [1]. U radu se koristi izraz za određivanje veličine glavnih naprezanja (1):

$\sigma_{1,2}=\frac{\sigma_{x x}}{2} \pm \frac{1}{2} \sqrt{\sigma_{x x}^{2}+4 \tau_{x y}^{2}}$

gdje su $\sigma_{x x}$ normalna naprezanja u poprečnom presjeku usmjerena duž osi grede, a $\tau_{x y}$ su posmična naprezanja u poprečnom presjeku usmjerena okomito na os grede.

\section{EKSPERIMENTALNA ANALIZA NAPREZANJA}

\subsection{Općenito o eksperimentalnoj analizi naprezanja}

U inženjerskoj praksi često se u složenijim konstrukcijama javljaju složena stanja naprezanja kao što su pojave koncentracije naprezanja na rubovima ili kutovima elemenata nepravilnih složenih oblika (razni pogonski dijelovi strojeva, avionska krila....), ili, našoj praksi bliža, pojava koncentracije naprezanja u gredama uslijed zasijecanja greda ili bušenja otvora u istima [3].

Analitičke metode analize naprezanja pogodne su za rješavanje jednostavnijih stanja naprezanja, dok za složenije konstrukcije za vrlo veliki broj problema postupak proračuna analitičkim metodama postaje previše složen i neprikladan za svakodnevno korištenje u inženjerskoj praksi. Stoga se pribjegava korištenju drugih metoda određivanja raspodjele naprezanja [3].

Neke eksperimentalne metode mogu se primijeniti samo na modelima, dok se druge mogu primijeniti i na izvedenim originalnim konstrukcijama. Pojedine metode pogodne su za laboratorijsku primjenu, dok su druge pogodnije za primjenu na terenu. Postoji veliki broj eksperimentalnih metoda analize naprezanja. Mnoge od njih su se razvile u čitave discipline. Neke važnije metode jesu [3]:

- fotoelasticimetrija

- tenzometrija

- metode akustičke emisije

- ostale optičke metode

- metoda rendgenskog zračenja 
U ovom se radu za eksperimentalno određivanje trajektorija glavnih naprezanja koristimo fotoelasticimetrijom upotrebom refleksijskog polariskopa.

\subsection{Fotoelasticimetrija}

Fotoelasticimetrija je optička metoda analize naprezanja koja iskorištava svojstvo fotoelastičnih materijala da u napregnutom stanju postaju dvolomni. Dvolom je pojava koja se javlja kada zraka svjetlosti prolazi kroz anizotropno sredstvo i pritom se lomi u dvije međusobno okomite linearno polarizirane zrake, a nastaje zbog toga što je brzina širenja svjetlosti u anizotropnim materijalima različita u različitim smjerovima. Veličina dvoloma ovisi o veličini i rasporedu naprezanja i može se mjeriti pomoću polariziranog svjetla u polariskopu [3].

\subsubsection{Polarizirano svjetlo}

Svjetlosne zrake su elektromagnetski valovi koji su po ponašanju slični radio valovima. Svjetlost se od izvora širi u svim smjerovima. Elektromagnetski valovi titraju u svim ravninama okomitim na smjer širenja svjetlosti [4]. Ukoliko koristimo polaroidni filter, kroz njega će biti propuštena samo jedna komponenta titranja, dok će ostale ravnine iščeznuti, odnosno polaroidni filter propušta samo jednu ravninu titranja svjetlosnih valova i to ravninu koja je je paralelna s osi polarizatora. Tako propuštena svjetlost naziva se polarizirana svjetlost. Intenzitet propuštene svjetlosti jest:

$$
A_{1}=A \cos \alpha
$$

gdje je A intenzitet izvora svjetlosti a $\alpha$ je kut između dva polarizatora. Mjerna jedinica intenziteta svjetla je kandela. Iz izraza (2) možemo zaključiti da će intenzitet svjetla, ukoliko su osi dvaju polarizatora međusobno okomite, biti jednaka nuli. U tom slučaju promatrač vidi tamni analizator (Slika 1) [4].

Na Slici 2 shematski je prikazan način rada reflektirajućeg polariskopa kakvoga koristimo za potrebe ovoga rada. Svjetlost se širi iz izvora svjetlosti kojeg uobičajeno predstavlja žarulja. Svjetlosni valovi se šire i prolaze kroz prvi polaroidni filter u kojemu se svjetlost polarizira. Polarizirano svjetlo širi se do fotoelastične ploče koja je zalijepljena na uzorak pomoću reflektirajućeg adheziva. Fotoelastična ploča napravljena je od posebne plastike. Za razliku od drugih homogenih materijala u stanju naprezanja, plastika se ponaša kao optički anizotropan materijal, odnosno uslijed opterećenja dolazi do promjene indeksa refrakcije koji je u funkciji 
rezultirajućeg naprezanja. Upravo to svojstvo čini plastiku pogodnom za korištenje u fotoelasticimetriji.

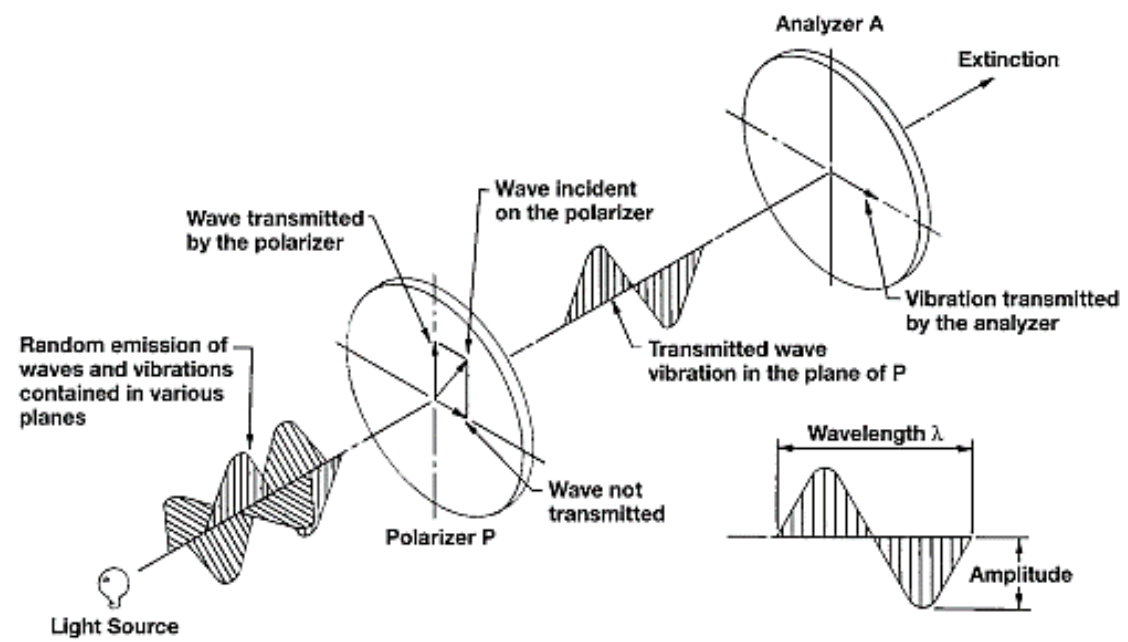

Slika 1. Prolaz polariziranog svjetla kroz analizator kada su polaroidni filteri ukršteni [4]

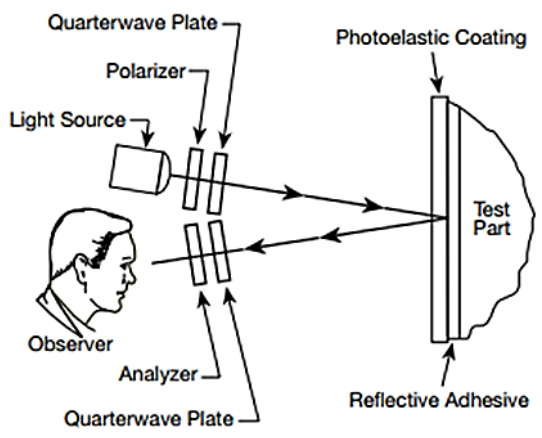

Slika 2. Shematski prikaz rada reflektirajućeg polariskopa [4]

Kada polarizirano svjetlo prolazi kroz fotoelastičnu ploču, vektor svjetlosti se rastavlja i projicira na dvije međusobno okomite komponente. Veličina komponenti vektora svjetlosti odredi se pomoću izraza (2). Kod polariziranog svjetla kakvo se koristi kod ispitivanja polariskopom, vektor svjetlosti je orijentiran na predvidiv način, za razliku od nepolariziranog svjetla kod kojeg je taj vektor orijentiran na slučajan način.

Zrake se od fotoelastične ploče reflektiraju i prolaze kroz analizator čija je optička os vodoravna (Slika 3), tako da će analizator apsorbirati vertikalne projekcije komponenata vektora svjetlosti, a propustiti njihove 
vodoravne projekcije A1 i A2 [4] budući da polaroidni filter propušta samo jednu ravninu titranja svjetlosnih valova i to onu ravninu koja je paralelna s osi polarizatora.

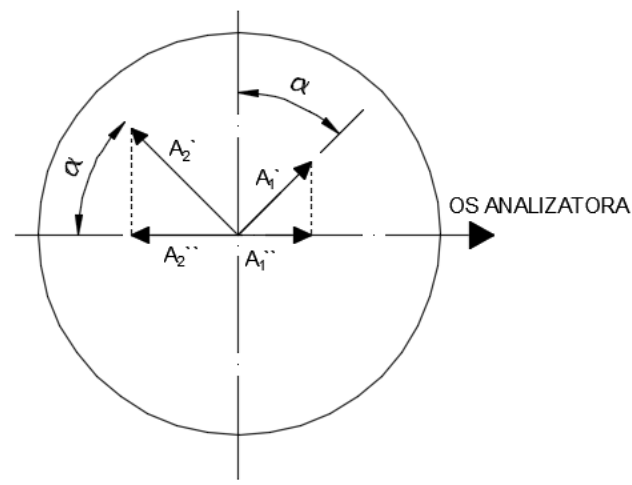

Slika 3. Rastavljanje vektora svjetla na komponente nakon prolaska kroz analizator [4]

3.2.2. Intrepretacija rezultata ispitivanja fotoelasticimetrijom i tamnih mjesta

\section{- Izokline}

Promatramo li napregnuti model kroz polariskop, na nekim mjestima na modelu uočavamo crne linije, ili pak crna polja. Takve crne linije nazivamo izokline. Ukoliko se prisjetimo poglavlja 3.2.1, gdje smo naveli da, ukoliko su osi polarizatora ukrštene, svjetlost iščezava i ostaje tamno polje, možemo lako zaključiti da crne linije i polja predstavljaju mjesta gdje su pravci glavnih deformacija na modelu paralelni s osi polarizatora te se kao rezultat pojavljuju tamna polja i linije.

Izoklina parametra $\alpha$ predstavlja liniju u kojoj pravci glavnih deformacija (ujedno i pravci glavnih naprezanja) zatvaraju kut $\alpha$ sa proizvoljno odabranom osi $x$ (obično vertikalna os modela.) Izoklinu parametra $\alpha$ dobivamo tako da osi polaroidnih filtera zajedno zaokrenemo za proizvoljan kut $\alpha$ od osi $x$ kako bi zadovoljili uvjet da osi polariskopa budu ukrštene i da možemo dobiti izoklinu. Pomoću izoklina može se odrediti kut koji glavna naprezanja zatvaraju sa koordinatnim osima.

\section{- Izokrome}

Opterećivanjem se u modelu javljaju deformacije koje se zorno prenose na fotelastičnu ploču. Deformacije u ploči stvaraju odgovarajuće optičke efekte koje pod polariskopom možemo vidjeti kao linije u raznim bojama i nazivamo ih izokromama. Bitno je napomenuti da izokrome predstavljaju linije istih boja.

Nanošenjem opterećenja na model dolazi do pojave naprezanja $u$ modelu, što se očituje u pojavi izokroma. Različita stanja naprezanja koja se 
javljaju u modelu u izokromama će se realizirati ne samo u obliku linije izokrome, već i u samoj boji izokrome. Na Slici 4 prikazana je propagacija boja izokroma ovisno o veličini realizirane deformacije. Boje koje su definirane na Slici 4 su komplementarne boje proizašle iz isključivanja pojedinih boja iz spektra bijele svjetlosti uslijed pomaka u fazi i valnoj duljini svjetlosnog vala. Zbog toga možemo primijetiti da se neke boje pojavljuju više puta, ali s različitim kontrastom kao rezultat isključivanja najprije jedne boje, a zatim više različitih boja iz spektra bijele svjetlosti zbog povećanja pomaka u fazi između dva vala u analizatoru. Iz Slike 5, možemo definirati veličine naprezanja promatrajući boje izokroma dobivenih iz polariskopa.

Pomoću Slike 5 možemo zornije prikazati promjenu izokroma u spektru boja ovisno o promjeni veličine naprezanja. Na Slici 5 tlocrtno je prikazana konzolna greda opterećena koncentriranom silom na slobodnom kraju. Možemo primijetiti da sa porastom naprezanja prema upetom kraju grede izokrome na gredi mijenjaju boju prema redu kakav je uspostavljen u tablici na Slici 4. Tako, na primjer, crna boja označava neopterećena područja modela, dok zelena boja označava područja najvećega naprezanja. Izokrome razlikujemo po boji, ali i po redu izokrome, kako je navedeno u krajnjem desnom stupcu Slike 4 („Fringe order").

Izokrome se uvijek javljaju u kontinuiranom redoslijedu, što znači da, ukoliko identificiramo izokrome prvog i trećeg reda, možemo zaključiti da se izokroma drugog reda nalazi između [4]. Slijed boja koje se pojavljuju u izokromama uvijek se uspostavlja prema redu utvrđenom na slikama 4 i 5 , ovisno o porastu ili smanjenju naprezanja.

\begin{tabular}{|c|c|c|c|}
\hline \multirow[t]{2}{*}{ COLOR } & \multicolumn{2}{|c|}{$\begin{array}{l}\text { APPROXIMATE } \\
\text { RELATIVE } \\
\text { RETARDATION }\end{array}$} & \multirow{2}{*}{$\begin{array}{c}\text { FRINGE } \\
\text { ORDER } \\
N\end{array}$} \\
\hline & $\mathrm{nm}$ & in $\times 10^{-6}$ & \\
\hline Black & 0 & 0 & 0 \\
\hline Pale Yellow & 345 & 14 & 0.60 \\
\hline Dull Red & 520 & 20 & 0.90 \\
\hline Red/Blue Transition & 575 & 22.7 & 1.00 \\
\hline Blue-Green & 700 & 28 & 1.22 \\
\hline Yellow & 800 & 32 & 1.39 \\
\hline Rose Red & 1050 & 42 & 1.82 \\
\hline Red/Green Transition & 1150 & 45.4 & 2.00 \\
\hline Green & 1350 & 53 & 2.35 \\
\hline Yellow & 1440 & 57 & 2.50 \\
\hline Red & 1520 & 60 & 2.65 \\
\hline Red/Green Transition & 1730 & 68 & 3.00 \\
\hline Green & 1800 & 71 & 3.10 \\
\hline
\end{tabular}

Slika 4. Redosljed pojavljivanja izokroma [4] 


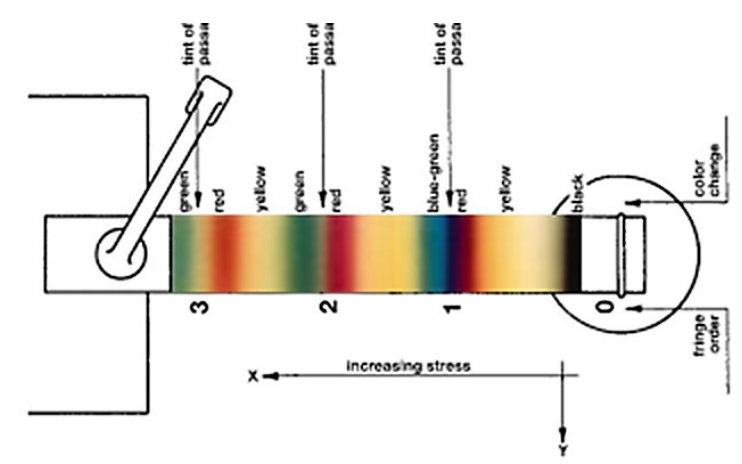

Slika 5. Propagacija izokroma na konzoli opterećenoj na slobodnom kraju [4]

Kod pokusa $\mathrm{u}$ kojem opterećenje na element povećavamo $\mathrm{u}$ inkrementima, izokrome nam mogu pokazati područja elementa koja su kritična i ona koja su manje iskorištena jer se izokrome najprije pojavljuju na najkritičnijim područjima, s porastom opterećenja šire se prema područjima koja su manje opterećena (tamna područja), dok na kritičnim mjestima nastaju nove izokrome viših redova [4].

\section{NUMERIČKI PRIMJER}

\subsection{Općenito o numeričkom primjeru}

U ovom poglavlju prikazat će se postupak i rezultati postavljenog numeričkoga primjera kojim ćemo obuhvatiti područje naprezanja i fotoelasticimetrije. Numeričkim primjerom prikazat ćemo raspodjelu naprezanja po dužini i visini opterećene grede. Raspodjelu naprezanja prikazujemo izobarama naprezanja. Numerički primjer riješen je analitičkim i eksperimentalnim putem $s$ naglaskom upravo na eksperimentalni dio. Zadatak je analitički riješen koristeći programski paket Wolfram Mathematica. Također je dan proračun u komercijalnom programu koji koristi metodu konačnih elemenata.

\subsection{Opis zadatka}

Drvena letvica širine $b=10 \mathrm{~mm}$ i visine $h=40 \mathrm{~mm}$ slobodno je oslonjena na osnom razmaku $L=1 \mathrm{~m}$ i opterećena koncentriranom silom od $250 \mathrm{~N}$ na sredini raspona (Slika 6). 


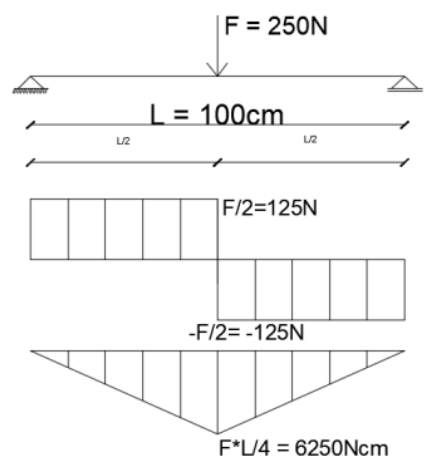

Slika 6. Statička skica grede i pripadajuće rezne sile.

Moment tromosti poprečnog presjeka izračunat je prema:

$I_{y}=\frac{b h^{3}}{12}=\frac{4^{3}}{12}=5.33 \mathrm{~cm}^{4}$

Statički moment površine pravokutnog poprečnog presjeka dan je sa:

$S_{y}=\frac{b}{2}\left(\frac{h^{2}}{4}-z^{2}\right)$

gdje veličina $z$ predstavlja udaljenost od težišta poprečnog presjeka.

Tangencijalna naprezanja izračunata su prema izrazu

$$
\tau_{x y}=\frac{T S_{y}}{I_{y} b}=T\left(\frac{3}{2 b h}-\frac{6 z^{2}}{b h^{3}}\right)
$$

gdje je $T$ poprečna sila u promatranom presjeku.

Normalna naprezanja izračunata su prema

$$
\sigma_{x x}= \pm \frac{M_{y} z}{I_{y}}
$$

gdje je $M_{y}$ moment savijanja u promatranom presjeku.

Raspodjela normalnih naprezanja po visini i dužini grede i raspodjela posmičnih naprezanja po visini grede dana je na Slici 7. 

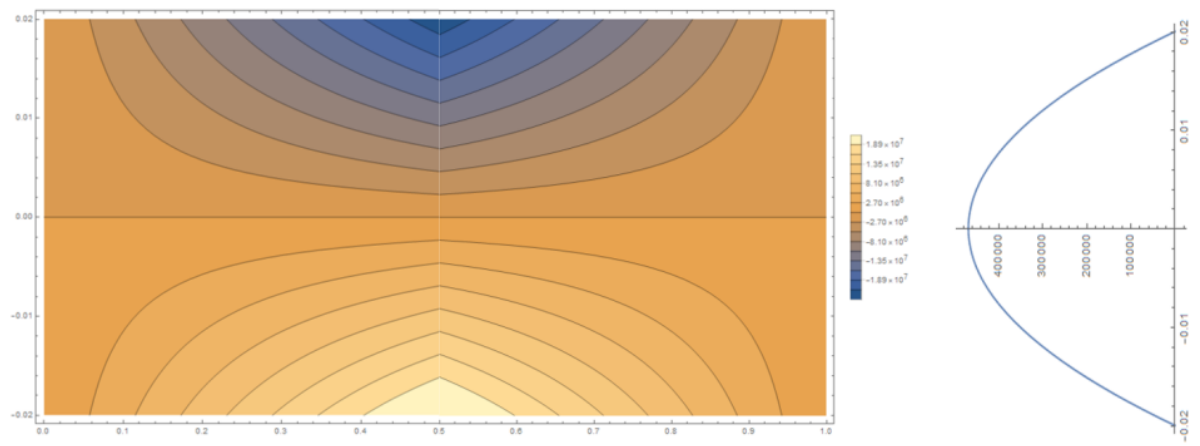

Slika 7. Raspodjela normalnih naprezanja po dužini i visini grede (lijevo) i raspodjela posmičnih naprezanja po visini grede (desno) $\left[\frac{\mathrm{N}}{\mathrm{mm}^{2}}\right]$.

Glavna naprezanja računata su prema (1). Mjesta na kojima se pojavljuju iste vrijednosti glavnih vlačnih i tlačnih naprezanja povezuju linije koje zovemo izobarama vlačnih/tlačnih naprezanja i dana su na Slikama 8 i 9.

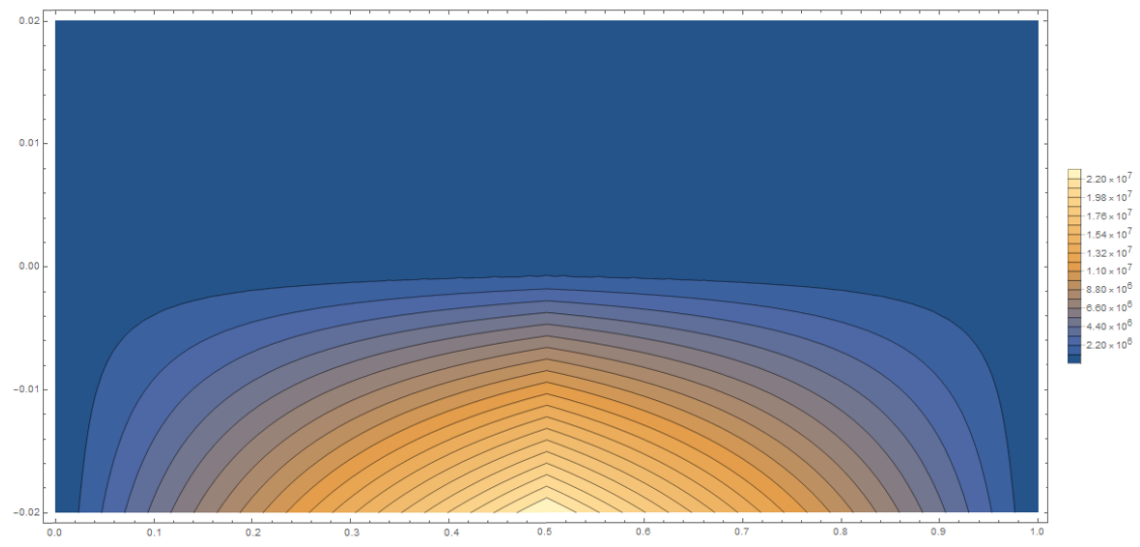

Slika 8. Izobare glavnih vlačnih naprezanja po dužini i visini grede $\left[\frac{N}{\mathrm{~mm}^{2}}\right]$. 


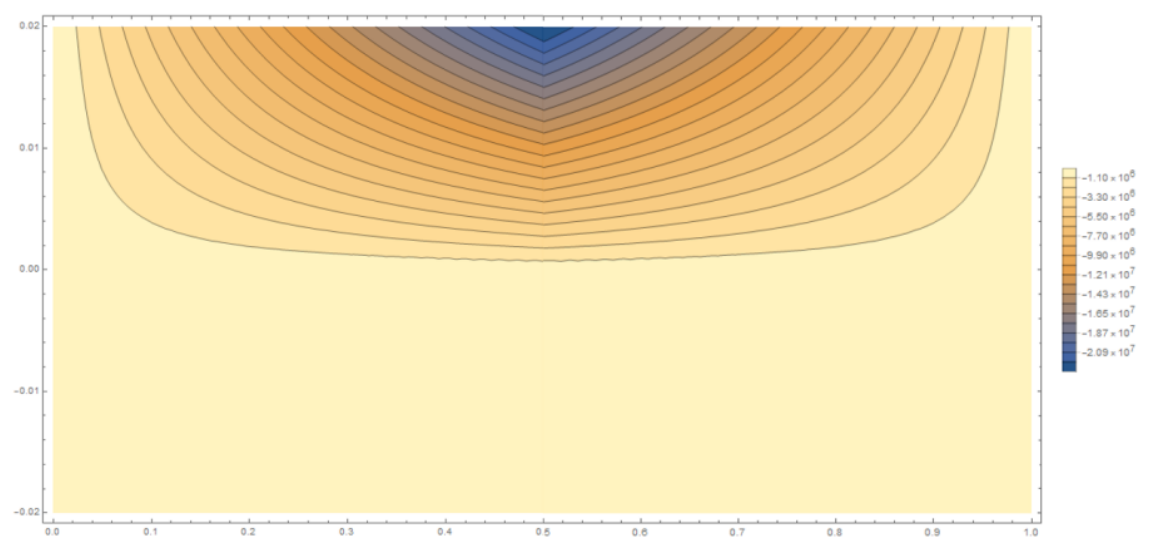

Slika 9. Izobare glavnih tlačnih naprezanja po dužini i visini grede $\left[\frac{N}{\mathrm{~mm}^{2}}\right]$.

\subsection{Izobare glavnih naprezanja}

Izobare glavnih naprezanja predstavljaju krivulje koje spajaju točke jednakih veličina glavnih naprezanja na napregnutom elementu. Izobare glavnih naprezanja definirane su samo veličinom glavnog naprezanja, ali ne i smjerom glavnog naprezanja. Bitno je napomenuti da izobare naprezanja nisu isto što i trajektorije naprezanja budući da linije izobara nisu i ne moraju biti tangente na krivulje glavnih naprezanja.

\subsection{Eksperimentalno ispitivanje}

\subsubsection{Priprema uzorka za ispitivanje}

Postupak započinje izrezivanjem ploče od posebne plastike na komade čije dimenzije odgovaraju uzorku kojeg ispitujemo. Fotoelastična plastika oznake $P S-3 A$ odabrana je prema uputama proizvođača [5]. U našem slučaju ploču smo izrezali na 4 komada dimenzija $4 \times 25 \mathrm{~cm}$ (Slika 10). Izrezane komade plastike, kao i samu gredu, potrebno je zatim oprezno očistiti vatom natopljenom alkoholom kako bi se uklonile eventualne nečistoće i prašina.

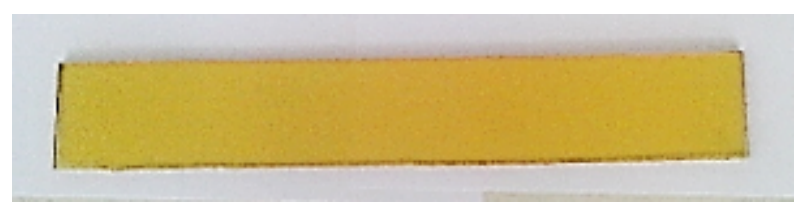

Slika 10. Komad posebne plastike dimenzija $4 \times 25 \mathrm{~cm}$.

Nakon pripreme plastike slijedi priprema adheziva $P C-6$ [5] pomoću kojega lijepimo plastiku za drvenu gredu. Dvokomponentni adheziv se priprema tako da komponente najprije maseno doziramo u omjeru 1:1. 
Proizvođač je propisao potrebnu masu adheziva po jedinici površine na temelju čega je za potrebnu površinu od $400 \mathrm{~cm}^{2}$ izračunato da je potrebno $50 \mathrm{~g}$ adheziva, odnosno $25 \mathrm{~g}$ učvršćivača (Hardener) te $25 \mathrm{~g}$ posebne smole (Resin). Dozirane komponente se zatim zagrijavaju na ploči na propisanu temperaturu od $45^{\circ} \mathrm{C}$. Nakon što se postigne tražena temperatura, komponente se zajedno miješaju 3-5 minuta dok se ne postigne homogena smjesa odgovarajuće temperature budući je kemijska reakcija vezivanja učvršćivača i smole egzotermna.

Adheziv kistom nanosimo na drvenu gredu u sloju debljine $1 \mathrm{~mm}$. Nakon nanošenja adheziva, komade plastike oprezno postavljamo na gredu tako da su rubovi plastike i grede poravnati. Plastiku zatim oprezno i nježno pritišćemo kako bi istisnuli sve mjehuriće zraka zarobljene između adheziva i plastike i ostvarili potpunu i kvalitetnu vezu između istih. Takvu gredu potrebno je ostaviti $24 h$ u mirovanju kako bi se adheziv osušio i greda bila spremna za ispitivanje pod polariskopom. Greda gotova za ispitivanje prikazana je na Slici 11.

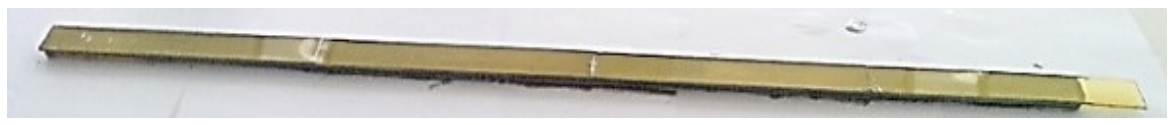

Slika 11. Greda gotova za ispitivanje.

\subsubsection{Ispitivanje grede}

Postupak ispitivanja započinjemo postavljanjem grede u okvir na kojeg smo prethodno pričvrstili oslonce na zadanom razmaku. Greda se zatim dodatno stabilizira kako bi se spriječila pojava bočne nestabilnosti, a koncentrirano opterećenje u sredini raspona naneseno je pomoću uređaja za nanošenje sile koji ujedno mjeri intenzitet nanesene sile (Slika 12). Polariskop je pozicioniran prema uputama proizvođača tako da je izvor svjetlosti okomit na plohu grede, a udaljenost polariskopa od grede iznosi $200 \mathrm{~cm}$.

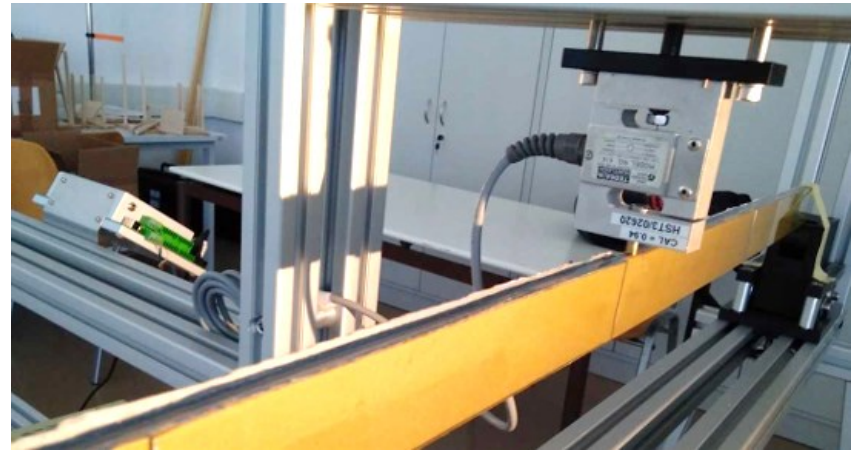

Slika 12. Gotova greda za ispitivanje. 
Postepenim nanošenjem opterećenja uzorak se deformira. Na analizatoru očitavamo pojavu izokroma i izoklina, kao i njihove pripadajuće boje, odnosno redove.

Na Slici 13 u sredini raspona na mjestu nanošenja sile mogu se primijetiti polja izokroma čije boje se kreću od svijetlo žute (0.6) do svjetlo zelene (1.22), gdje broj u zagradi označava red izokrome. Udaljavajući se od točke nanošenja opterećenja dolazi do pojave crnih polja (0) koja predstavljaju mjesta koja nisu napregnuta. Oblik i boja, odnosno red izokroma u točki nanošenja opterećenja upućuju na izrazitu koncentraciju i složenu raspodjelu naprezanja u tom području.

Udaljavajući se od sredine raspona prema osloncima dominantno je tamno polje (crna izokroma), uz izuzetak na rubovima greda gdje su naprezanja najveća pa dolazi do slabog odmaka prema svijetlo žutoj izokromi. Razlog što su izokrome tako slabo vidljive u tom području možemo potražiti između nekoliko faktora:

- velika krutost grede

- neadekvatno sprječavanje bočne nestabilnosti zbog čega dolazi do bočnog izvijanja

- izobare se teže vide na niskim gredama

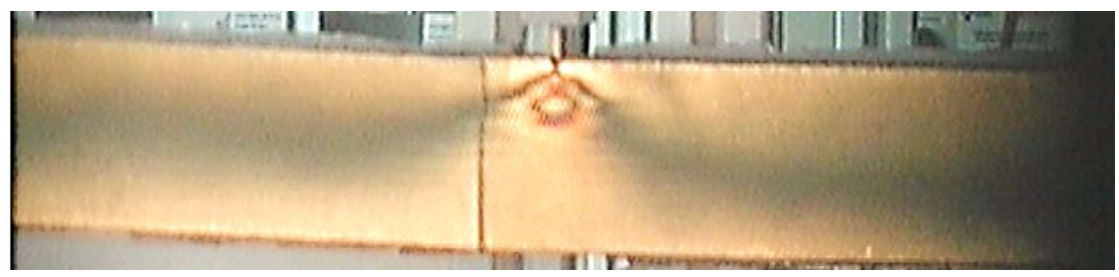

Slika 13. Greda podvrgnuta opterećenju od $243 \mathrm{~N}$.

Daljnjim povećanjem opterećenja, na Slici 14 može se uočiti pojačavanje koncentracije naprezanja kao i žute boje na rubovima grede i postepeno smanjivanje tamnog polja. Daljnjim povećanjem opterećenja, izokroma (0) bi se smanjivala prema središtu presjeka grede.

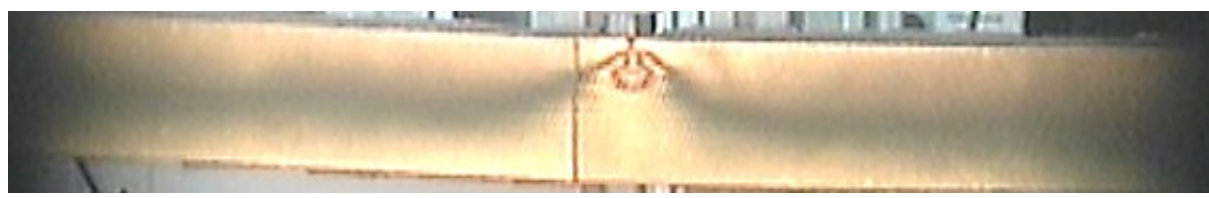

Slika 14. Greda podvrgnuta opterećenju od $291 \mathrm{~N}$.

Na samom mjestu oslanjanja ponovo dolazimo do zanimljivog otklona u izobarama glavnih naprezanja dobivenim putem polariskopa i onih dobivenih analitički. Koncentracija naprezanja jasno je vidljiva na Slici 15, a 
rezultirajuće izokrome kreću se od svijetlo žute $(0,60)$ sve do crvene boje $(2,65)$.

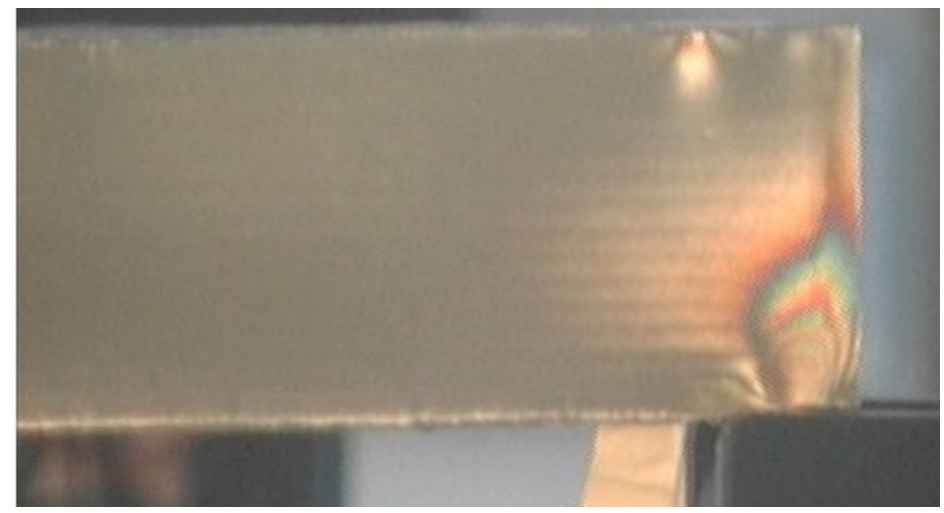

Slika 15. Greda podvrgnuta opterećenju od $291 \mathrm{~N}$-područje oslonca.

Zbog nedostatka adekvatne opreme kojom bi se greda bolje učvrstila, oslonila i na kraju preciznije opteretila, maksimalna sila kojom je greda opterećena iznosi $291 \mathrm{~N}$. Pri tom stanju naprezanja izokrome jednostavno nisu dovoljno vidljive da bi se iz njih mogla kvalitetno odrediti raspodjela naprezanja u gredi, niti potvrditi rezultati dobiveni analitičkom analizom.

Kao zamjenski sustav korištena je skraćena greda raspona $25 \mathrm{~cm}$, od posebne reflektirajuće plastike. Dimenzije poprečnog presjeka iznose $3 \times$ $40 \mathrm{~mm}$. Sama plastika je vrlo mekana i ima malu krutost, što je povoljno za jasnoću izokroma i jednostavnost ispitivanja, ali mana takvog materijala jesu velike zaostale deformacije. Sama greda oslonjena je na prijašnju gredu kako bi izokrome bile vidljive. Zamjenska greda pričvršćena je za drvenu gredu pomoću ljepljive trake. Stoga u daljnjim slikama na zamjenskoj gredi neće doći do pojave tako izražene koncentracije naprezanja u području oslanjanja kao u prethodnom primjeru.

U prvom koraku opterećenja, na Slici 16 možemo uočiti već tri para izokroma, od svijetlo žute do prijelazne crveno plave izokrome (1). Također možemo primijetiti, kao i kod prijašnje grede, da na mjestu unosa sile dolazi do pojave koncentracije naprezanja.

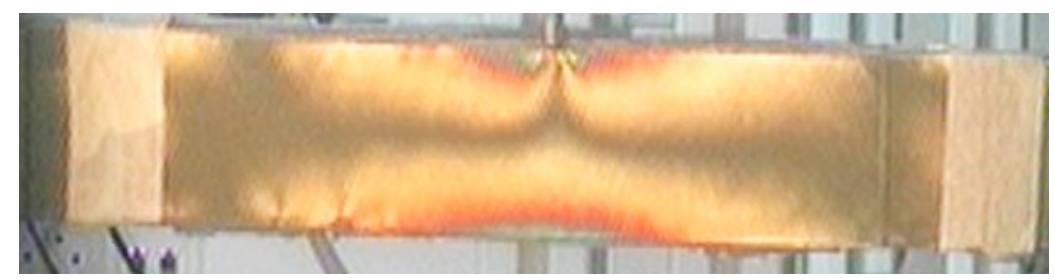

Slika 16. Zamjenska greda podvrgnuta opterećenju, prvi korak opterećenja. 
U drugom koraku dodavanja opterećenja, na gredi možemo uočiti kako se pojavljuju nove izokrome dok se prijašnje izokrome potiskuju prema središtu grede. Izokrome se ne šire samo prema središtu, već i u dužinu, prema samim osloncima. Ukoliko se u trećem poglavlju prisjetimo kako se izokrome pojavljuju i šire, možemo lako zaključiti koja su područja grede kritična, a koja su neiskorištena. Na Slici 17 možemo uvidjeti kako se počinju nazirati i koncentracije naprezanja na improviziranim ležajima u kutovima zalijepljene trake. Vrlo je bitno napomenuti da bi se daljnjim opterećivanjem drvene grede u prethodnom primjeru uz adekvatnu opremu dobio jednaki oblik izokroma, odnosno raspodjele naprezanja u gredi, kao u primjeru zamjenske grede.

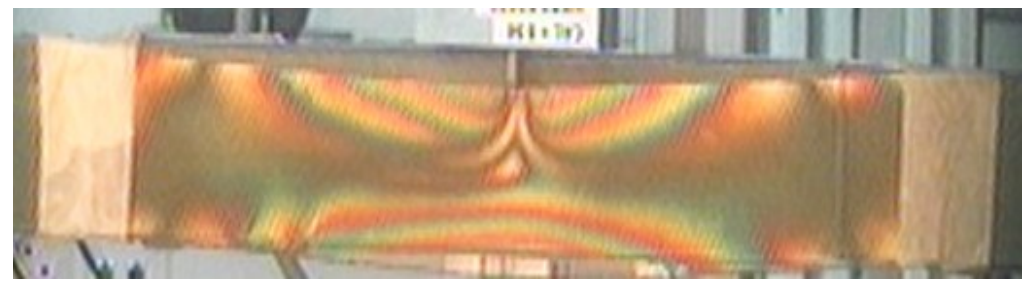

Slika 17. Zamjenska greda podvrgnuta opterećenju, treći korak opterećenja.

Budući u radu koristimo grednu teoriju koja nije u stanju prepoznati koncentracije naprezanja te time nismo u mogućnosti validirati analitičke i eksperimentalne rezultate, dodatno je napravljen model u programskom paketu STAAD.Pro sa pločastim konačnim elementima, a rezultati su prikazani na Slici 18.

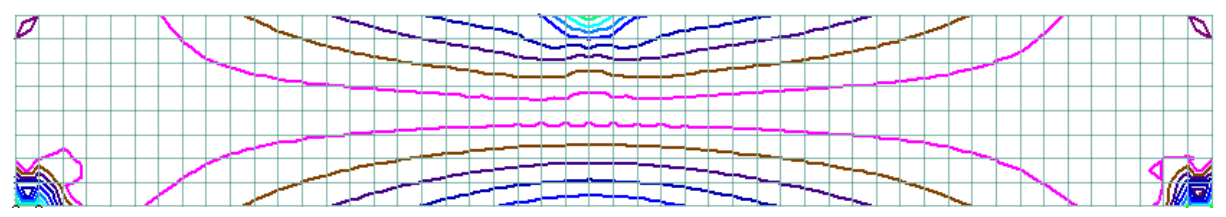

Slika 18. Prikaz izobara naprezanja na modelu grede u programskom paketu STAAD.Pro.

\section{Zaključak}

Cilj ovoga rada je prikazati izobare glavnih naprezanja dobivenih analitičkim putem i eksperimentalnim putem. Uspoređujući rezultate možemo potvrditi da se izobare glavnih naprezanja dobivene analitičkim putem i eksperimentalnim putem podudaraju u područjima između oslonaca i mjesta unosa koncentrirane sile (središte raspona). Na mjestima unosa opterećenja ili oslanjanja, u eksperimentalnom djelu primjera uočena 
su složena stanja naprezanja (koncentracija naprezanja) te veliki otklon u rezultatima u odnosu na dobiveno analitičko rješenje. Takvi rezultati su i očekivani budući u analitičkom proračunu koristimo grednu teoriju koja nije u stanju prepoznati postojanje normalnih naprezanja okomitih na os nosača koja se javljaju na osloncima i na mjestu unosa koncentrirane sile. Klasična teorija kontinuuma u ravnini prepoznaje takvu koncentraciju naprezanja, što je i potvrđeno modelom grede napravljenom u programskom paketu STAAD.Pro.

Eksperimentalne metode pogodne su za korištenje u složenim konstrukcijama kada su analitički postupci ili previše složeni ili nepouzdani zbog primjene neodgovarajuće teorije ili nepostojanja adekvatne teorije. U takvim konstrukcijama, fotoelasticimetrija, osim raspodjele naprezanja, može uvelike pomoći u otkrivanju preopterećenih ili neopterećenih dijelova konstrukcije i time pomoći inženjeru u oblikovanju ekonomičnije konstrukcije.

Ovaj rad daje veliki doprinos prvenstveno budućim studentima na kolegiju Otpornost materijala II kojima će ovaj rad uvelike pomoći u savladavanju pojma glavnih naprezanja i raspodjele naprezanja $u$ jednostavnijim elementima. Daljnji cilj ovoga rada je i potaknuti na daljnja istraživanja u području fotoelasticimetrije.

Zahvala. Ovaj je članak rezultat rada u okviru projekta Razvoj istraživačke infrastrukture na kampusu Sveučilišta u Rijeci(RC.2.2.06-0001) koji je sufinanciran iz Europskog fonda za regionalni razvoj (EFRR) $i$ Ministarstva znanosti, obrazovanja i sporta RH (This work has been supported in part by Ministry of Science, Education and Sports of the Republic of Croatia under the project Research Infrastructure for Campus-based Laboratories at the University of Rijeka, number RC.2.2.06-0001. Project has been co-funded by the European Fund for Regional Development (ERDF)).

\section{Literatura}

[1] V. Šimić, Otpornost materijala I, Školska knjiga, Zagreb, 2002.

[2] F. P. Beer, E. Russel Johnston, Jr, J. T. Dewolf and D. F. Mazurek, Mechanics of Materials, McGraw-Hill, New York, 2009.

[3] Alfirević, Nauka o čvrstoći I, Tehnička knjiga, Zagreb, 1989.

[4] Tech note TN-702-2, Vishay Micro-Measurements

[5] Tech note TN-704-2, Vishay Micro-Measurements 